\title{
3D Printing Applied to Tissue Engineered Vascular Grafts
}

\author{
Raphaël Wenger ${ }^{1,2}$ and Marie-Noëlle Giraud 1,2,* \\ 1 Cardiology, Faculty of Sciences and medicine, University of Fribourg, 1700 Fribourg, Switzerland; \\ raphael.wenger@hefr.ch \\ 2 University of Bern, 3000 Bern, Switzerland \\ * Correspondence: marie-noelle.giraud@unifr.ch; Tel.: +41-26-300-8531
}

Received: 22 November 2018; Accepted: 11 December 2018; Published: 15 December 2018

\begin{abstract}
The broad clinical use of synthetic vascular grafts for vascular diseases is limited by their thrombogenicity and low patency rate, especially for vessels with a diameter inferior to $6 \mathrm{~mm}$. Alternatives such as tissue-engineered vascular grafts (TEVGs), have gained increasing interest. Among the different manufacturing approaches, 3D bioprinting presents numerous advantages and enables the fabrication of multi-scale, multi-material, and multicellular tissues with heterogeneous and functional intrinsic structures. Extrusion-, inkjet- and light-based 3D printing techniques have been used for the fabrication of TEVG out of hydrogels, cells, and/or solid polymers. This review discusses the state-of-the-art research on the use of 3D printing for TEVG with a focus on the biomaterials and deposition methods.
\end{abstract}

Keywords: 3D printing; bioprinting; additive manufacturing; tissue engineering; blood vessels; vascular grafting

\section{Introduction}

For a broad spectrum of vascular diseases, the bypass of blocked blood vessels is performed using a vascular graft. The surgeons anastomose the graft with a healthy vessel and reconnect the blood flow downstream. A vascular bypass is a common surgical procedure for limb salvage following critical limb ischemia and various peripheral vascular diseases associated with diabetes, atherosclerosis, or aging, and is a prevailing therapeutic option for coronary artery diseases [1]. Vascular prostheses are also essential for arteriovenous fistulae, hemodialysis vascular access, and large vessel reconstruction-linked congenital defects or aneurysms.

For vessels with a diameter larger than $6 \mathrm{~mm}$, synthetic grafts made with polymers, such as polyethylene terephthalate (PET, Dacron $\left.{ }^{\circledR}\right)$, expanded polytetrafluoroethylene (ePTFE, Goretex $\left.{ }^{\circledR}\right)$ and polyurethanes (PU) are preferred. The resistance of blood flow and the risk of thrombosis are low. Well-documented performance investigations confirmed their adequate compliance for low shear stress. Major advantages include biocompatibility, a broad availability of forms and sizes, cost-effectiveness, and favorable surgical handling [2].

For applications, such as peripheral and coronary bypasses that require small diameter grafts, the benchmark vascular grafts are autologous, including the internal mammary artery, the radial artery from the arm, and the saphenous vein from the leg [1]. Although very successful in a majority of patients, the lack of natural grafts is a concern for approximately $30 \%$ of those who need multiple grafts or have vascular diseases. Small diameter synthetic grafts are also available; however, their long-term patency rate is impaired by intima hyperplasia, thrombosis, and infection. Blood flow disturbance and wall shear stress that emerge from the mechanical property differences between the grafts and the native artery induce a biological response. An initial endothelial injury is followed by 
platelet activation, migration of smooth muscle cells (SMCs), and production of extracellular matrix, resulting in the thickening of the vessel wall, referred to as intima hyperplasia, and thrombosis. The consequent decrease in graft patency is responsible for vascular failure [3,4].

To address these issues, the development of tissue-engineered vascular grafts (TEVGs) has flourished in recent decades. The next generation of small diameter grafts should present some important improvements. Adequate compliance and mechanical strength that can sustain high pressure and pulsatile flow, optimal anti-thrombotic capacity, and long-term patency are key features that must be addressed. Several strategies for vascular grafts have emerged with a clear preference for biological active multilayer grafts combining cell and biomaterials with a native-like structure. Native vessels are composed of several layers. From the lumen, the first important layer is the endothelium. This monolayer of endothelial cells (ECs) is in direct contact with the blood, provides anti-thrombotic protection, and controls SMC function and homeostasis. The protective layer is challenged by variations in blood flow and pressure. An injured endothelium promotes smooth muscle cell migration and consequent intima hyperplasia. The vessel wall is composed of successive layers of extracellular matrices, SMCs, and fibroblasts. The SMCs regulate the lumen diameter and contractility of the vessel. Oriented layers of elastin and collagen provide the vessels' mechanical properties, such as compliance and strength.

Engineering a functional blood vessel relies on the following principles:

1. A rapid formation of a functional endothelial layer at the surface of the graft increases the hemocompatibility of TEVG by decreasing the occurrence of early thrombosis [5] and late hyperplasia [6]. The endothelialization of the grafts can be achieved either in vitro or in vivo. In vitro, the grafts seeded with ECs are maintained in culture until a functional endothelial monolayer forms. The sources of ECs vary from human autologous ECs, human umbilical vein endothelial cells (HUVECs), stem cell-derived ECs, or CD34 ${ }^{+}$endothelial progenitor cells (EPCs). In vivo, endothelization is promoted by the EPCs recruited into the implanted grafts from the host circulation and/or by the migration of ECs from the adjacent artery. However, to achieve sufficient migration of ECs and recruitment of EPCs, the stimulation of cell adhesion and the use of chemoattractants are important.

2. Both the matrix and the manufacturing process control the structural integrity and mechanical properties (such as burst strength and elastic modulus). As an example, the elastic modulus of a healthy human aorta was reported to be in the range of $1.5 \mathrm{MPa}$ and varies with age and health status $[7,8]$. In addition, the scaffold design influences cell migration and consequent neotissue formation. In particular, the presence of pores within the scaffolds and their size have been identified as important factors for host cells recruitment. The cells colonize the scaffold, produce their own extracellular matrix, and foster vessel regeneration, as well as graft patency [9].

3. The addition of SMCs, fibroblasts, or stem cells within the vessel wall may be beneficial. Lee et al., [10] provided evidence that the cell content of the implanted TEVGs correlates with the patency rate. Even though the seeded cells disappear from the grafts within a few days, it was demonstrated that they stimulate the host response in a paracrine manner, via the release of growth factors and cytokines, and promote remodeling and regeneration [11]. As a consequence, initially seeded cells are replaced by a neotissue. The evidence of the remodeling process of the TEVG post-implantation has fostered the idea that biodegradable biomaterials may be appropriate if the vessel integrity is maintained for several weeks, while extracellular matrix (ECM) produced by the host cells replaces the scaffold material as it degrades, allowing the development of an autologous graft [12].

4. Finally, the anchorage of specific biologically active molecules to the scaffolds stimulates the in-situ remodeling and the regenerative process and therefore limits hyperplasia.

Accordingly, the tissue-engineered strategies for TEVG corresponding to biomaterial-centered and/or cell-based approaches have led to the development of a broad variety of combinations of cells and scaffolds. Recent investigations have shed light on promising TEVG composed of synthetic vascular grafts seeded with either endothelial cells [13], adipocyte-derived vascular cells [14] or 
bone marrow mononuclear derived cells [15]. Other TEVGs development provided evidence of the feasibility of using bioresorbable scaffold [12] or decellularized biological matrices, such as the bioengineered human acellular vessel (HAV) [16]. In this approach, human vascular smooth muscle cells (hVSMCs) were seeded into polyglycolic acid polymer scaffolds and subjected to pulsatile distension for 8 weeks before the removal of the cells with detergents, preserving the tubular structure composed of extracellular matrix proteins. Furthermore, scaffold-free grafts composed of fibroblast and SMC sheets rolled on a mandrel to produce a tubular structure (named Tissue Engineering by Self-Assembly (TESA) [17]) have been successfully developed.

To date, several biological active vascular prostheses have been tested in clinical trials for vessel reconstruction in pediatric patients with congenital cardiac diseases [18], peripheral arterial disease [14] and hemodialysis access [16,17]. Nevertheless, at the moment, no biological active vascular grafts have received market approval from the Food and drug Administration.

The urgent need for small diameter TEVGs has challenged the scientific community and resulted in the development of numerous multi-disciplinary approaches. Regarding the complexity of the multilayered vessel structure, 3D printing has opened new avenues for the engineering of structures composed of cells, growth factors, and scaffolds assembled in an organized way. In the present review, we specifically address the use of 3D printing for the fabrication of TEVGs and describe various combinations of deposition techniques, biomaterials, and cells.

\section{3D Printing Techniques Used for TEVG (Tissue-Engineered Vascular Graft)}

3D Printing offers the possibility of engineering complex biomedical devices and tissues according to computer design and patient-specific anatomical data. A 3D printing platform consists of a computer-controlled axis system combined with one or more layer-by-layer processes. 3D printing enables the bypassing of time-consuming and expensive steps of subtractive manufacturing or casting processes, including the preparation of molds for plastic injection or metal casting. This technology is especially interesting for fast prototyping, small series production, and customized devices. Since its initial use for pre-surgical training models and tooling molds, 3D Printing has slowly evolved to create unique and customized implants, engineered tissues, and drug delivery systems. 3D printed modules and frameworks are already used in many medical fields, such as orthopedics, neurosurgery, cardiothoracic surgery, and dentistry [19]. Additionally, 3D printers can be used in combination with $3 \mathrm{D}$ radiologic [20] or optical scansion devices [21] in order to allow a customized clinical treatment. The general 3D printing workflow consists of:

1. Designing a 3D model (eventually based on patient-specific 3D imaging);

2. Converting the 3D model to data for the manufacturing process (tool path or 2D slices);

3. Manufacturing the model by a digitally controlled deposition or cross-linking process;

4. Post-processing for bulk or surface modifications [22].

The main techniques used for 3D printing of biological materials are inkjet, micro-extrusion and laser-assisted printing [23-25].

\subsection{Extrusion}

Extrusion printers operate by the automated displacement of an extrusion system that deposits material onto a substrate in three dimensions. Directed by the controller of the platform, continuous strands of material are deposited in two dimensions. After the completion of a layer, either the stage or the extrusion head is moved along the z-axis, and the deposited layer serves as a foundation for the next layer. A myriad of biomaterials is compatible with extrusion printers, including hydrogels, polymers, and cell suspension or aggregates. The most common methods used to extrude biological materials for 3D bioprinting applications are pneumatic pistons, mechanical pistons, or screw extruding systems. The coaxial extrusion has gained popularity for the bioprinting of hollow tubes [26-30]. A nozzle made of two or more concentric needles permits the simultaneous deposition 
of multiple materials in concentric rings. When used for tissue engineering applications, the controlled deposit of a bioink forms a hollow tube (outer channel) that is filled with a cross-linking solution or cell suspension (inner channel).

\subsection{Inkjet}

Inkjet printing consists of ejecting drops of material from a nozzle onto a substrate with a narrow range of printable viscosity $(<15 \mathrm{mPa} \cdot \mathrm{s})$, limiting the choice of printable biomaterials. In comparison with other processes, inkjet printing offers fast and precise deposition. However, it is not suitable for the printing of bioinks laden with a high density of cells, since their number increases the overall viscosity of the ink [31]. Piezoelectric and mechanical micro-valve drop-on-demand inkjet are the most common bioprinting techniques [32,33]. As compared to other inkjet methods, micro-valve inkjet typically allows for the jetting of liquids with higher viscosities under a higher pressure, thanks to the mechanical closing of the nozzle. The drawback of such a system is the drop size, which is larger than other inkjet methods [34].

Concerning piezoelectric inkjet, the pulse voltage has a significant impact on cell survival, with an increased cell death observed at $80 \mathrm{~V}$ as compared to $40 \mathrm{~V}$ [35]. As the voltage on the piezoelectric actuator within the printhead increased, the resulting pressure-wave amplitude also increased, leading to a higher stress on the cells ejected from the nozzle. However, despite the harsh conditions, the cell viability remained above $95 \%$. Although no studies have been done to investigate the possibility of cell membrane damage or induced apoptosis, these results show a higher viability than that reported for thermal inkjet printing studies.

\subsection{Light-Based Systems}

Light-based systems use the energy carried by light for the selective cross-linking of photosensitive polymer precursors. For tissue engineering applications, stereolithography (SLA), two-photon polymerization (2PP), as well as digital light processing (DLP), have been investigated. SLA and 2PP mostly use mirrors to move the focal point of one or more lasers, scanning one layer after the other. $2 \mathrm{PP}$ allows for printing with the highest resolution $(<100 \mathrm{~nm})$. However, it is not well suited for the processing of large objects $(>1 \mathrm{~cm})$ as the printing may take days to weeks. DLP printers use an array of micromirrors, just like a projector, to create a mask to polymerize one full layer at a time [36,37].

\section{Three-Dimensional Printing Strategies for TEVG}

Driven by the principle that the next generation of TEVG would ideally mimic the structure and function of the native vessels, 3D printing has emerged as a promising manufacturing process. This process offers multiple possibilities of controlling the spatial arrangement of the elements that compose the constructs and tuning the chemical and mechanical properties [38-41]. Among the strategies developed, we have distinguished between the investigations centered on the 3D printing of the scaffolds, and the ones introducing a second level of complexity by processing both cells and scaffolds via 3D bioprinting.

\subsection{Three-Dimensional Printing of Scaffolds}

As summarized in Table 1, the 3D printing approaches for TEVG support the creation of straight or branched tubular structures, using synthetic or natural biomaterials. The choice of the biomaterials is driven by several considerations, including their mechanical properties, biocompatibility, and biodegradation behavior (mechanism, kinetics, metabolites) [42]. One of the advantages of synthetic polymers is the high reproducibility of their properties, independent of batch variability. The molecular weight, crystallinity, internal organization, and degree of cross-linking are important tunable attributes that can be adjusted during the synthesis, or later, as a post-treatment [31,43-46]. As a substitute for synthetic biomaterials, natural polymers extracted from animal and plants have been broadly investigated. Depending on their origin and processing, they generally present biological cues suited to promote 
desirable cell responses, and are favorable for cell attachment. Their mechanical properties can be tuned by chemical modification (i.e., cross-linking) to match the application.

Table 1. 3D printing (acellular printing). B, Branched, S, Straight; A, aggregate, Sp, spheroids, S, cell suspension in bioink; D, Diameter, OD, outer diameter, ID, inner diameter; T, thickness, L, length, P, Pores size; MSC, Mesenchymal Stem Cell; HASMC, Human aortic smooth muscle cell; HA-VSMC, Human Aortic Vascular Smooth Muscle Cell; HUVEC, Human Umbilical Vein Endothelial Cell; HDF-n, Human Dermal Fibroblasts-neonatal; hMSC, Human Mesenchymal Stem Cell; HUVSMC, Human Umbilical Vein Smooth Muscle Cell.

\begin{tabular}{|c|c|c|c|c|c|c|}
\hline $\begin{array}{l}\text { Manufacturing } \\
\text { Process }\end{array}$ & Acellular Materials & $\begin{array}{l}\text { Cell-Laden } \\
\text { Material }\end{array}$ & $\begin{array}{c}\text { Manually } \\
\text { Seeded Cells }\end{array}$ & Dimensions & Tubes & Reference \\
\hline \multirow{5}{*}{ Extrusion } & $\begin{array}{l}\text { PCL (scaffold) } \\
\text { PVA (support) }\end{array}$ & - & - & D: $2-4 \mathrm{~mm}$ & B & [47] \\
\hline & $\begin{array}{l}\text { PCL (scaffold) } \\
\text { gelMA-gellan } \\
\text { (scaffold) } \\
\text { Alginate (support) }\end{array}$ & Gelatin & $\operatorname{MSC}(\mathrm{S})$ & D: $4 \mathrm{~mm}$ & S & [47] \\
\hline & $\begin{array}{l}\text { Fibin (support) } \\
\text { PDMS (support) }\end{array}$ & Medium & $\operatorname{HASMC}(\mathrm{A})$ & D: $5 \mathrm{~mm}$ & S & [48] \\
\hline & $\begin{array}{l}\text { Alginate (scaffold) } \\
\text { Cacl2(bath) }\end{array}$ & - & - & D: $1-3 \mathrm{~mm}$ & B & [49] \\
\hline & Silicone (scaffold) & $\begin{array}{l}\text { dECM } \\
\text { Medium } \\
\text { Medium }\end{array}$ & $\begin{array}{c}\text { HA-VSMC (S) } \\
\text { HUVEC (S) } \\
\text { HDF-n (S) }\end{array}$ & D: $0.5-2 \mathrm{~mm}$ & $\mathrm{~S}$ & {$[50]$} \\
\hline \multirow{3}{*}{ DLP } & PU & - & - & $\begin{array}{l}\text { OD: } 4 \mathrm{~mm} \\
\text { ID: } 1.5 \mathrm{~mm}\end{array}$ & S & [51] \\
\hline & PPF & Fibrin & $\begin{array}{l}\text { Sp of } 50 \% \\
\text { HUVEC and } \\
50 \% \text { hMSC }\end{array}$ & $\begin{array}{l}\text { ID: } 2.5 \mathrm{~mm} \\
\text { T: } 0.25 \mathrm{~mm} \\
\text { P: } 0.35 \mathrm{~mm}\end{array}$ & $\mathrm{~S}$ & [52] \\
\hline & PPF & - & $\begin{array}{l}\text { HUVEC (S) } \\
\text { HUSMC (S) }\end{array}$ & $\begin{array}{l}\text { ID: } 1 \mathrm{~mm} \\
\text { T: } 0.15 \mathrm{~mm}\end{array}$ & S & [53] \\
\hline SLA & PTHD-DA & - & - & $\begin{array}{l}\text { D: } 2 \mathrm{~mm} \\
\text { T: } 0.1 \mathrm{~mm}\end{array}$ & S & [54] \\
\hline $2 \mathrm{PP}$ & PTHD-DA & - & - & $\begin{array}{l}\text { ID: } 18 \mu \mathrm{m} \\
\text { T: } 3 \mu \mathrm{m} \\
\text { L: } 160 \mu \mathrm{m}\end{array}$ & $\mathrm{B}$ & [54] \\
\hline Inkjet & $\begin{array}{l}\text { Alginate (bath) } \\
\mathrm{CaCl} 2 \text { (jetted) }\end{array}$ & - & SMC (S) & $\begin{array}{l}\text { D: } 2 \mu \mathrm{m} \\
\mathrm{L}: 2 \mathrm{~mm} \\
\mathrm{~T}: 2 \mathrm{~mm}\end{array}$ & S & [55] \\
\hline \multirow{2}{*}{$\begin{array}{l}\text { Electrospinning } \\
\text { and extrusion }\end{array}$} & $\begin{array}{c}\text { Blend PCL-Chitosan } \\
\text { (wall), PCL } \\
\text { (reinforcement) }\end{array}$ & - & - & - & S & {$[56]$} \\
\hline & $\begin{array}{l}\text { Heparin-releasing } \\
\text { PLLA (wall), PCL } \\
\text { (reinforcement) }\end{array}$ & Medium & - & $\begin{array}{l}\text { D: } 5 \mathrm{~mm} \\
\mathrm{~L}: 6 \mathrm{~cm}\end{array}$ & S & {$[57,58]$} \\
\hline
\end{tabular}

Natural and synthetic polymers can be 3D printed in two forms: As solid polymers or as hydrogels. Solid polymers are mostly hydrophobic and do not significantly absorb water, thus are not permeable to water-soluble molecules. This implies that, without the addition of pores, the exchanges of gases (i.e., oxygen), signaling molecules, and metabolites is obstructed. Hydrogels, on the other hand, are cross-linked 3D networks of hydrophilic polymers, already swollen in water, allowing for the diffusion of water-soluble molecules [59,60].

The creation and implantation of an acellular, vessel-like structure, is based on the assumption that biocompatible scaffolds allow the migration and the engraftment of the host cells within the printed structure, resulting in the formation of a neotissue. The choice to add cells to the printed 
structure prior to implantation remains an open option taking into consideration the balance between increased time and complexity of the graft preparation, and the improved stimulation of vessel regeneration. In order to create cellularized constructs, cells are seeded and grown on or into printed structures. First, a tubular structure is produced; next, a simple pipetting procedure seeds the appropriate cells on or into the printed structures. The constructs are matured over the course of several days to weeks in an incubator, prior to in vivo implantation. A more sophisticated approach, consisting of printing both the cells and the biomaterials, is described in Section 3.2.

\section{Poly (propylene fumarate) (PPF)}

PPF is a biodegradable polyester, often used in laser-based additive manufacturing as a UV resin, together with diethyl fumarate as the solvent, and bisacrylphosphrine oxide as the photoinitiator [61]. The variation of the solvent to resin ratio allows for the tuning of viscosity before cross-linking, and mechanical strength of the 3D model. Acellular vascular grafts composed of photo-cross-linked PPF were produced by DLP [53]. Melchiorri et al. printed PPF-scaffolds with an inner diameter of $1 \mathrm{~mm}$ and a wall thickness of $150 \mu \mathrm{m}$, with adequate long-term mechanical stability and suturability. After 100 flashes of the UV lamp, the 3D-printed PPF samples demonstrated an ultimate tensile strength of 1.48 MPa and an elastic modulus of $8.79 \mathrm{MPa}$, within the range of native femoral artery and saphenous vein. The acellular grafts were implanted in the venous system of mice for 6 months and maintained an optimal patency throughout this period. ECM remodeling and a confluent endothelialization of the lumen surface were observed, suggesting that the implants could indeed support neotissue formation in vivo. However, an extended inflammation was observed in the newly formed tissue, suggesting a strong foreign body reaction.

\section{Polyurethane (PU)}

$\overline{\mathrm{PU}}$ is a non-bioresorbable polymer with a high mechanical strength. Its main components are polycaprolactone diol and a second oligodiol containing amphiphilic blocks [62]. Biodegradability can be engineered by tethering with hydrolysis-prone segments. Recently, PU was modified into a hydrogel that can undergo thermal gelation and biodegradation [63]. Tubular constructs derived from PU biodegradable hydrogels were achieved via DLP and included complex micro-architectures, such as high porosity and interconnectivity [51]. The group improved the suture tear resistance of the constructs by developing a resin, based on urethane-diacrylate monomers, which exhibited a reduced cross-linking density. The observed mechanical properties were within the range of those of native ovine carotid arteries.

\section{Polytetrahydrofuran diacrylate (PTHF-DA)}

PTHF-DA is a non-bioresorbable, commercially available resin that can easily be used as a UV ink through the addition of a photo-initiator. The ratio of the photo-initiator to the resin influences its photosensitivity, while the chain length of the pre-polymer influences the viscosity of the resin and the mechanical properties of the 3D model. Meyer et al used PTHF-DA with SLA to engineer bifurcating acellular tubes with a diameter of $2 \mathrm{~mm}$ [54]. The elastic modulus was reduced from 30 to $6 \mathrm{MPa}$ by increasing the molar mass of the pre-polymer. The biocompatibility investigations of the photo-cross-linked material showed in vitro cytocompatibility with human dermal fibroblasts. In addition, the authors provided evidence that to produce smaller diameters, e.g., capillary vessels, $2 \mathrm{PP}$ is more appropriate as it allows for sub-micrometer resolution $[54,64]$.

\section{Alginate}

Alginate is derived from seaweed and bacteria [65] and is a popular natural polymer used for 3D printing of scaffolds or as a sacrificial material. Its gelation can be controlled by the addition of non-toxic ionic cross-linking agents, such as calcium chloride $\left(\mathrm{CaCl}_{2}\right)$. One critical drawback of ionically cross-linked alginate hydrogels is the release of water-soluble cations into the surrounding liquids. Nevertheless, covalent cross-linking using Poly (ethylene glycol) (PEG), as well as photo cross-linking, using methacrylates and photoinitiators, allows for more stable hydrogels, and for the tuning of their 
mechanical properties. Alginate is not biodegradable by mammalian cells, as they lack the enzyme (i.e., alginase) to cleave the polymer chains.

In a pioneer investigation, the fabrication of tubular hydrogel structures by drop-on-demand inkjet printing was achieved by modifying a Hewlett Packard standard printer to jet the $\mathrm{CaCl}_{2}$ solution into an alginate bath with a z-stage that moved the substrate after each layer was printed [55]. Between the layers, SMCs were manually pipetted to ensure their encapsulation in the construct. Because of the difficulty to achieve precise patterns when using ionic $\mathrm{CaCl}_{2}$ cross-linking, and the fragility of the model, the printing process could not be used to engineer high aspect ratio constructs. The inner diameters, wall thicknesses, and heights of the resulting structures were each $2 \mathrm{~mm}$. Interestingly, the construct was cultured for 18 days and showed vasoreactivity to agonists while remaining mechanically suitable for manipulation.

In an innovative approach, named freeform reversible embedding of suspended hydrogels (FRESH), alginate-based hollow tubular structures were created with the use of a sacrificial material. An alginate solution was extruded into a supporting gelatin $/ \mathrm{CaCl}_{2}$ hydrogel bath to print branched coronary artery structures [49]. Gelatin was added to the bath and thermally converted into a gel in order to prevent the alginate construct's collapse during the printing process. By providing a continuous support of the printed model, this approach enables the fabrication of soft structures with mechanical integrity. To remove the construct from the bath, the gelatin was heated above its liquefaction point. A structural analysis compared the 3D model with the 3D printed arterial tree and showed high accuracy of the printed structure, with measured variations of less than $15 \%$ in the overall length and width, and less than $3^{\circ}$ difference in the angles of the major bifurcations. When perfused with black ink, the arterial tree showed no leakage through the wall, confirming an appropriate fusion of the alginate wall.

\section{$\underline{\text { Silicone }}$}

Xu et al. constructed small-diameter blood vessels using a multi-nozzle 3D bioprinting system [50]. A double-layered silicone (SE1700) tubular structure was produced by extrusion and post-processing laser drilling to form micropores within the structure. The mechanical properties of the silicone supporting structure were tuned to reach $244 \mathrm{kPa}$ for a wall thickness of $150 \mu \mathrm{m}$ in order to maintain the vessel structural integrity. The space between the inner and outer layers was filled with human aortic vascular smooth muscle cells (HA-VSMCs) embedded in a decellularized extracellular matrix (dECM) to form the Media. HUVECS were seeded inside of the channel to form the Intima. Human dermal fibroblasts-neonatal (HDF-n) were seeded outside to form the Adventitia. The complete complex process allowed the successful formation of a three-layered structure similar to that of native vessels.

\section{Polycaprolactone (PCL)}

PCL is an FDA approved biodegradable polyester with a resorption time of two to three years through hydrolysis [66]. Its high elongation at break and low stiffness provide major advantages over other polymers for low-bearing applications with deformations. To tune the mechanical properties of the printed structures, PCL has often been combined with other polymers.

Using extrusion, Visser et al. produced various multi-material anatomically shaped tissue constructs [47]. For a vascular branched model, two extrusion heads were used: One printing a PCL structure with large pores, the other depositing a temporary polyvinyl alcohol (PVA) support. Alternatively, the authors extruded a gelatin methacrylamide (GelMA)-gellan hydrogel tube that was reinforced with PCL fibers and alginate support structures. The addition of gellan gum improved the shape-fidelity of the GelMA hydrogel without affecting cell viability. The removal of the PCL fibers and dissolution of the alginate supports resulted in a hydrogel tube with an open lumen, into which a mesenchymal stem cell (MSC) -laden gelatin hydrogel was injected.

Interestingly, PCL has also been used in mixed procedures combining 3D printing with electrospinning of nanofibers. This combined approach has recently emerged and holds great potential. Nanofiber-based scaffolds have a high surface-area-to-volume ratio and intrinsic porosity, favorable for cell integration, 
while the control of the fiber orientation enables the fabrication of anisotropic implants [67-69]. Artificial blood vessels were produced by first electrospinning nanofibers from a biomaterial prone to cell attachment on a cylinder. Subsequently, the electrospun tubes were wrapped in an extruded, thicker polymer coil in order to improve the mechanical properties of the vessel [56]. Lee et al. tested CTS (chitosan), PCL, and blended CTS/PCL as an electrospun material, combined with wrapping in a PCL coil. Water absorption, and therefore hydrophilicity (which promotes cell adhesion), increased in correlation to the increase in the CTS content of the nanofibers. The addition of the thick strand of PCL around the electrospun tube led to an increase of the elasticity modulus and ultimate tensile strength of the vessel.

Using a similar principle, electrospinning of a heparin-eluding Poly-L-Lactic Acid (PLLA) tube, combined with a thicker PCL coil extruded on the outer wall, was investigated [58]. The low patency rate observed in grafts made of PLLA alone, due to acute graft thrombotic occlusion, was improved with the addition of heparin. The acellular hybrid graft had a stress-strain profile comparable to that of the human thoracic artery. Human mesenchymal stem cells (hMSCs) were seeded into the construct and showed proliferation and differentiation into ECs. In vivo, the graft was used to bypass the aorta for $4 \mathrm{~cm}$ in a rabbit model. All the grafts remained patent throughout implantation, and no thrombosis or structural graft failure was detected. Endogenous endothelial-like cells lined the lumen of the grafts, while cells within the graft wall displayed characteristics of fibroblasts, and the outer layers of the graft were colonized with cells resembling fibroblasts or SMCs.

\subsection{Bioprinting}

Bioprinting enables the fabrication of multi-scale, multi-material, and multicellular tissues with heterogeneous and functional intrinsic structures [70]. With this approach, the engineered tissues present native-like mechanical and structural properties, as well as suitable handling capacities for anastomosis between blood vessels.

Bioprinting strategy refers to the incorporation of 3D printed cells in the scaffold. This often implies the functionalization of the scaffold with peptide or protein to achieve tissue maturation. The major remaining challenge is the definition of an optimal bioink and the tailoring of printing techniques allowing high cell viability throughout the manufacturing process. Living cells are printed as a suspension in biomaterials or as aggregates (spheroids or pellets) (Table 2). In the last decade, cell spheroids became popular thanks to novel fabrication and 3D culture techniques. The 3D multicellular arrangement promotes cell-to-cell interaction, leading to an improved tissue-like maturation, as compared to standard 2D cultures. Cell spheroids self-assemble into a fused tissue when placed closely together [71].

Hydrogels are the most popular biomaterials found in bioinks [78,79]. The water-swollen gels made of 3D hydrophilic polymeric structures are held together by one or multiple forces. These forces can be of different natures, the most common being covalent cross-links, hydrogen bonds, and ionic forces [80].

\section{Agarose}

Agarose was one of the first biomaterials investigated for bioprinting. This natural polysaccharide, extracted from reed seaweed, is an inert material with low cell adherence properties. Nevertheless, upon blending with collagen, cell adhesion and viability improved [81]. It is used as a hydrogel in molds for cell aggregation, or as a bioink, with embedded, non-adhering cells [82]. It becomes a gel around $40{ }^{\circ} \mathrm{C}$, but remains quite viscous even when melted. In 2009, an initial study [72] extruded agarose as a support for different types of cells, including human umbilical vein smooth muscle cells (HUVSMCs) alone, and in combination with a layer of human splenic fibroblasts (HSFs), as well as SMCs alone. The cells were deposited through extrusion, first as a spheroid and later as cell pellets cast in a cylindrical shape. Fusion of the spheroids was observed after 2-4 days, at which point the agarose support was manually removed. Scaffold-free vessels with a 0.9 to $2.5 \mathrm{~mm}$ diameter were engineered and maintained for 7 days. 
Table 2. Bioprinting (cell-laden bioink printing) B, Branched, S, Straight; A, aggregate, Sp, spheroids, S, cell suspension in bioink; D, Diameter, OD, outer diameter, ID, inner diameter; T, thickness, L, length; HUVSMC, Human Umbilical Vein Smooth Muscle Cells; HSF, Human Splenic Fibroblasts; SMC, Smooth Muscle Cells; MEF, Mouse Embryonic Fibroblasts; U87-MG, Human glioma U87-MG cells; HASMC, Human Aortic Smooth Muscle Cells; NHDF, Normal Human Dermal Fibroblasts; MSC, Mesenchymal Stem Cells; NIH 3T3, Mouse Embryonic Fibroblast Cell Line; HUASMC, Human Umbilical Artery Smooth Muscle Cells.

\begin{tabular}{|c|c|c|c|c|c|c|}
\hline $\begin{array}{l}\text { Manufacturing } \\
\text { Process }\end{array}$ & $\begin{array}{l}\text { Acellular } \\
\text { Materials }\end{array}$ & Bioink & Bioprinted Cells & Dimensions & Tubes & Reference \\
\hline \multirow{3}{*}{ Extrusion } & Agarose (mold) & - & $\begin{array}{l}\text { HUVSMC, HSF, } \\
\text { SMC (A) }\end{array}$ & $\begin{array}{l}\text { D: } 0.9-2.5 \mathrm{~mm} \\
\text { L: } 7-10 \mathrm{~cm}\end{array}$ & B & [72] \\
\hline & $\begin{array}{l}\text { NovoGel }^{\circledR} \\
\text { (support) }\end{array}$ & - & $\operatorname{MEF}(\mathrm{A})$ & $\begin{array}{l}\text { D: } 9 \mathrm{~mm} \\
\text { H: } 3.5 \mathrm{~mm}\end{array}$ & & [73] \\
\hline & $\begin{array}{c}\mathrm{CaCl}_{2} \text { (bath) } \\
\mathrm{BaCl}_{2} \\
\text { (post-treatment) }\end{array}$ & Alginate & U87-MG (S) & D: $7.5-20 \mathrm{~mm}$ & $\mathrm{~S}$ & [46] \\
\hline $\begin{array}{c}\text { Extrusion } \\
\text { combined with } \\
\text { SLA }\end{array}$ & PCL (support) & PEG-co-PDP & HUVEC (S) & $\begin{array}{l}\text { OD: } 5 \mathrm{~mm} \\
\text { ID: } 3 \mathrm{~mm} \\
\text { L: } 20 \mathrm{~mm}\end{array}$ & B & {$[74,75]$} \\
\hline $\begin{array}{c}\text { Suction - } \\
\text { deposition of } \\
\text { spheroids on a } \\
\text { needle array }\end{array}$ & - & - & $\begin{array}{c}\text { Sp of } 40 \% \text { HUVEC, } \\
10 \% \text { HASMC and } \\
50 \% \text { NHDF }\end{array}$ & $\begin{array}{l}\mathrm{D}: 1.5 \mathrm{~mm} \\
\mathrm{~L}: 7 \mathrm{~mm}\end{array}$ & $\mathrm{~S}$ & [76] \\
\hline \multirow[t]{2}{*}{ Coaxial extrusion } & $\begin{array}{l}\mathrm{CaCl}_{2} \text { (sheath and } \\
\text { core sections) }\end{array}$ & $\begin{array}{l}\text { Blend of Alginate, } \\
\text { GelMA and } \\
\text { PEGTA }\end{array}$ & MSC, HUVECS (S) & D: $0.5-1.5 \mathrm{~mm}$ & $\mathrm{~S}$ & [26] \\
\hline & $\begin{array}{l}\mathrm{CaCl}_{2} \text { (sheath and } \\
\text { core sections) }\end{array}$ & Alginate & HUVSMC (S) & D: $1 \mathrm{~mm}$ & $\mathrm{~S}$ & [27] \\
\hline Inkjet & $\mathrm{CaCl}_{2}$ (bath) & Alginate & NIH 3T3 (S) & $\begin{array}{l}\text { D: } 3 \mathrm{~mm} \\
\mathrm{~L}: 10 \mathrm{~mm}\end{array}$ & B & [77] \\
\hline Microvalve inkjet & - & $\begin{array}{l}\text { Gelatin } \\
\text { Fibrin } \\
\text { Collagen }\end{array}$ & $\begin{array}{c}\text { HUVEC (S) } \\
\text { HUASMC (S) } \\
\text { NHDF (S) }\end{array}$ & $\begin{array}{l}\text { D: } 1 \mathrm{~mm} \\
\text { T: } 425 \mu \mathrm{m} \\
\text { L: } 16 \mathrm{~mm}\end{array}$ & $\mathrm{~S}$ & [38] \\
\hline
\end{tabular}

\section{Alginate}

Alginate is the most popular biocompatible hydrogel used in bioinks. Extruding alginate laden with human glioma U87-MG cells (U87-MGs) into a CaCl2 bath allowed the formation of tubular hydrogel structures [46]. The viability of the cells was $93 \%$ immediately after printing and $88 \%$ after 11 days of in vitro cell culture. A 2 min post-printing treatment of the model in $\mathrm{BaCl}_{2}$ solution improved the mechanical stability of the construct, prevented its degradation and increased cell viability. Cell proliferation through the gel and intercellular interaction were observed, implying good porosity of the alginate hydrogel.

Based on the same biomaterials, Zhang et al. [27] used coaxial extrusion to print alginate laden with HUVSMCs from the outer nozzle, and cross-linking $\mathrm{CaCl}_{2}$ solution from the inner nozzle. The cell viability was initially quite low (33\%), but increased to $84 \%$ after 7 days in culture. Cell activity was confirmed by extra-cellular matrix deposition on both the peripheral and luminal surfaces. Increasing the alginate concentration led to an increased mechanical strength and stability over time, as well as an improved printability. However, the porosity was reduced, leading to a lower cell viability and permeability of the construct.

Using a similar approach, vascular-like structures with bifurcations have been successfully printed from jetted alginate, as well as from mouse fibroblast-laden alginate, into a $\mathrm{CaCl}_{2}$ bath [77]. The $\mathrm{CaCl}_{2}$ solution in the bath had two functions: A cross-linking agent for the alginate, and a support material for printing of the overhanging region, as its density is very close to that of cross-linked alginate. In this study, particular attention was given to the shape-fidelity of the engineered model, and a heuristic approach was implemented to improve it. The modification of the printing trajectories along the 
circumferential and axial directions improved the shape-fidelity of tubular structures with bifurcations. The cell viability of the construct was $92.4 \%$ immediately after printing and $90.8 \%$ after $24 \mathrm{~h}$.

Furthermore, a photosensitive bioink, composed of sodium alginate blended with gelatin methacryloyl (GelMA) and 4-arm poly (-ethylene glycol)-tetra-acrylate (PEGTA), was printed by coaxial extrusion to form perfusable vascular constructs [26]. Upon coaxial extrusion, the hydrogel was first ionically cross-linked by $\mathrm{CaCl}_{2}$, followed by UV cross-linking and dissolution of the alginate to add porosity to the hollow tube wall. Four-armed PEGTA, as compared to the more common 2-armed PEG, allowed a higher cross-linking density, leading to increased mechanical strength while retaining porosity. Multiple multilayered coaxial nozzles were designed for continuous generation of perfusable constructs with hollow interiors and diameters up to $1.6 \mathrm{~mm}$ in a single step process. The direct deposition of the blended photosensitive bioink supported the proliferation and early maturation of vascular cells while remaining printable in a complex 3D vasculature. MSCs and HUVECs were encapsulated together in the bioink, and cultured for up to 21 days using a perfusion bioreactor. Over time, cell migration, spreading, proliferation, as well as MSCs differentiation in SMCs was observed. However, in the meantime, the mechanical properties of the construct deteriorated, due to the degradation of GelMA by the cells.

\section{Fibrin, collagen and gelatin}

Another interesting hydrogel, fibrin, is derived from the reaction of the enzyme thrombin on the glycoprotein fibrinogen, both extracted from mammalian plasma. In vivo, it combines with platelets to clot wounds in blood vessels. The combination of the two components required for its polymerization makes it well suited for inkjet bioprinting. The main drawbacks of fibrin are its degradation time, which is quick and thus not ideal for the long-term culture of cells, and the difficulty controlling its enzymatic polymerization kinetics. [82,83]. Human aortic smooth muscle cells (HASMCs) were seeded on fibrin hydrogel to self-organize into a tubular form resembling a natural artery ring [48]. The gel, aided by the innate contractile properties of the SMCs, migrated towards the center post insert, creating a tissue ring of SMCs. These rings were then stacked into the final tubular construct with an inner diameter of $5 \mathrm{~mm}$. Contractility of the construct was observed after 4 days, and mechanical properties were measured after 3 days. Its ultimate circumferential tensile strength was measured to be $191 \mathrm{kPa}$, which is 3 orders of magnitude lower than that of a natural tunica media layer of a common iliac artery (188 MPa), but was still high enough to allow for an easy manipulation of the construct.

Collagen, a well-known protein, is the main component of natural ECM in mammals. Most hydrogels use type I collagen extracted from rat-tail tendon, porcine skin, and bovine skin. Collagen fibrils self-assemble into bundled fibers at neutral $\mathrm{pH}$. In the presence of water-based solvents, these fibers interact and form a hydrogel. The final properties of the hydrogel depend on the collagen source and polymerization kinetics [84]. Furthermore, the mechanical properties of the collagen fibers can be improved by introducing chemical cross-linkers. The enzymatic degradation of collagen is mediated by the metalloprotease, secreted by the cells.

Gelatin is a biodegradable collagen-based hydrogel that undergoes thermoreversible gelation when its temperature drops below its gel point. The addition of methacrylate groups and photoinitiators makes gelatin photopolymerizable. It then cross-links when exposed to light irradiation to form a hydrogel, with mechanical properties tunable through the ratio of the photo-cross-linker present in the pre-polymer solution [85].

Recently, Schöneberg et al. used mechanical microvalve inkjet to generate in vitro blood vessel models in a bioreactor directly. These TEVGs consisted of a continuous endothelium (HUVEC) imitating the Intima, a human umbilical artery smooth muscle cell (HUASMC) layer mimicking the Media, and a surrounding fibrous and collagenous matrix of normal human dermal fibroblasts (NHDFs) mimicking the Adventitia [38]. HUVECs were suspended in gelatin, HUASMCs in fibrinogen and NHDFs in collagen. The drops were jetted onto the polyether-ether-ketone (PEEK) surface of a chamber that was connected directly to a flow generator. Within the flow bioreactor, the TEVGs were cultivated for up to 3 weeks under physiological conditions. The cell viability was $>83 \%$ immediately 
after printing, and the expression of VE-Cadherin, smooth muscle actin, and collagen IV throughout the cultivation period showed that the multilayered wall remained biofunctional.

Poly (ethylene glycol) (PEG)

As an alternative to the natural hydrogel, Poly (ethylene glycol) (PEG) is a synthetic hydrogel that is commonly modified with photoinitiators and either diacrylate or methacrylate to become photo cross-linkable [86]. Being synthetic, PEG does not suffer from the batch-to-batch variability and ethical concerns of natural polymers. PEG itself does not allow for cell adhesion and biodegradation, which makes it directly suitable for implantation where the adhesion of tissues must be prevented over long periods [87]. It can be modified with arginine-glycine-aspartic acid (RGD) peptide, found within many adhesion proteins, to allow for cell attachment $[88,89]$. Furthermore, by adding degradable cross-linkers and co-polymers during their fabrications, PEG hydrogels can be modified to become bioresorbable [90].

Combining the photo-cross-linking of a self-standing vascular graft with the extrusion of a porous rigid scaffold permitted the creation of a perfusable tissue construct. A biodegradable, photo-cross-linkable poly (ethylene glycol-co-depsipeptide) (PEG-co-PDP) macromere resin was formulated for visible-light SLA fabrication of a cell-laden hydrogel. First, SLA alone was used to manufacture a soft tubular construct out of HUVEC-laden hydrogel resulting in a high shape fidelity [74]. Next, a hybrid bioprinting technique, combining the photo-polymerization of this hydrogel with the extrusion of a solid polymer was developed [75]. A mechanically robust PCL scaffold was extruded simultaneously with the photo-cross-linking of the soft, cell-laden, vascular tubing within the scaffold to form a perfusable, multi-material construct. With this hybrid technique, the mechanical strength of the hydrogel was observed to be as high as that of the surrounding scaffold. $83-95 \%$ of cells in the hybrid constructs were alive upon bioprinting and $6 \mathrm{~h}$ after. Cell proliferation was observed for up to 10 days in culture.

\section{NovoGel ${ }^{\circledR}$}

The inert gel, NovoGel ${ }^{\circledR}$ (Organovo), specifically developed for bioprinting, was investigated to create an aorta vascular construct [73]. Based on medical images, Kucukgu et al. mostly focused on the workflow to bioprint an object based on 3D images. Cells were aggregated into a cylindrical pellet prior to feeding into the extrusion system and subsequently deposited. Mouse embryonic fibroblast (MEF) cell aggregates, using $\mathrm{NovoGel}^{\circledR}$ as a support structure, were extruded layer-by-layer, according to the proposed self-supported method to form an aortic tissue construct. The tissue was incubated for 4 days and the cell strands seemed to merge into aorta ring-like tissue precursors.

\section{Scaffold-free vascular construct}

Lastly, scaffold-free constructs were generated by suction and deposition of multicellular spheroids on a needle array [76]. A total of 500 multicellular spheroids composed of HUVECs $(40 \%)$, HASMCs $(10 \%)$, and NHDFs $(50 \%)$ was deposited with a 3D printer, forming a tubular structure. The constructs were cultured with a perfusion system for 6 days before implantation into the abdominal aortas of F344 nude rats for 5 days. The flow within the TEVG was assessed by ultrasonography and histological examinations performed on the second and fifth day after implantation. All grafts remained patent, and remodeling of the tubular tissues (enlargement of the lumen area and thinning of the wall) was observed. A layer of ECs lining the lumen was confirmed five days after implantation.

\section{Conclusions}

Three-dimensional printing is a rapidly developing area for tissue engineering and is preferred for achieving models with heterogeneous properties close to those of native tissues. Additive manufacturing is the only process that allows the engineering of branched TEVGs in a single fabrication step. Still, the biomanufacturing of printed TEVGs is in its infancy and lacks a consensus on the best fabrication process. In the future, 3D bioprinting using biocompatible inks will foster the creation of small diameter vascular grafts. The investigation of bioinks, based on decellularized ECMs and autologous cells, will promote the creation of new, clinically driven development for vascular grafts. 
Additionally, the assessment of TEVG functionality should be increasingly implemented and further studies are needed both in vitro and in vivo, in order to explore different application possibilities and interactions with other medical technologies. The synergy of multi-disciplinary collaborations between clinicians, biologists, chemists, and engineers will foster these developments. Moreover, increasing the implementation of a time dimension, often designated as $4 \mathrm{D}$ printing, will support the development of mature structures and functional TEVG. Finally, the versatility and ability to tailor TEVG using 3D printing will be essential for personalized medicine.

Author Contributions: Writing—Draft Preparation, R.W., M.-N.G.; Writing—Review and Editing, R.W., M.-N.G.; Supervision, M.-N.G.; Funding Acquisition, M.-N.G.

Funding: This research was funded by the University of Fribourg.

Acknowledgments: We thank Alexandra Hickey for the proofreading of the manuscript.

Conflicts of Interest: The authors declare no conflict of interest.

\section{References}

1. Tillman, B.; Hardin-Young, J.; Shannon, W.; Russell, A.J.; Parenteau, N.L. Meeting the need for regenerative therapies: Translation-focused analysis of U.S. regenerative medicine opportunities in cardiovascular and peripheral vascular medicine using detailed incidence data. Tissue Eng. Part B Rev. 2013, 19, 99-115. [CrossRef] [PubMed]

2. Zhang, W.J.; Liu, W.; Cui, L.; Cao, Y. Tissue engineering of blood vessel. J. Cell. Mol. Med. 2007, 11, 945-957. [CrossRef] [PubMed]

3. Salacinski, H.J.; Goldner, S.; Giudiceandrea, A.; Hamilton, G.; Seifalian, A.M.; Edwards, A.; Carson, R.J. The Mechanical Behavior of Vascular Grafts: A Review. J. Biomater. Appl. 2001, 15, 241-278. [CrossRef] [PubMed]

4. Seifu, D.G.; Purnama, A.; Mequanint, K.; Mantovani, D. Small-diameter vascular tissue engineering. Nat. Rev. Cardiol. 2013, 10, 410-421. [CrossRef] [PubMed]

5. Schneider, P.A.; Hanson, S.R.; Price, T.M.; Harker, L.A. Preformed confluent endothelial cell monolayers prevent early platelet deposition on vascular prostheses in baboons. J. Vasc. Surg. 1988, 8, 229-235. [CrossRef]

6. Dardik, A.; Liu, A.; Ballermann, B.J. Chronic in vitro shear stress stimulates endothelial cell retention on prosthetic vascular grafts and reduces subsequent in vivo neointimal thickness. J. Vasc. Surg. 1999, 29, 157-167. [CrossRef]

7. Guinea, G.V.; Atienza, J.M.; Rojo, F.J.; García-Herrera, C.M.; Yiqun, L.; Claes, E.; Goicolea, J.M.; García-Montero, C.; Burgos, R.L.; Goicolea, F.J.; et al. Factors influencing the mechanical behaviour of healthy human descending thoracic aorta. Physiol. Meas. 2010, 31, 1553-1565. [CrossRef]

8. Kohn, J.C.; Lampi, M.C.; Reinhart-King, C.A. Age-related vascular stiffening: Causes and consequences. Front. Genet. 2015, 6, 112. [CrossRef]

9. Zhang, Z.; Wang, Z.; Liu, S.; Kodama, M. Pore size, tissue ingrowth, and endothelialization of small-diameter microporous polyurethane vascular prostheses. Biomaterials 2004, 25, 177-187. [CrossRef]

10. Lee, Y.-U.; Mahler, N.; Best, C.A.; Tara, S.; Sugiura, T.; Lee, A.Y.; Yi, T.; Hibino, N.; Shinoka, T.; Breuer, C. Rational design of an improved tissue-engineered vascular graft: Determining the optimal cell dose and incubation time. Regen. Med. 2016, 11, 159-167. [CrossRef]

11. Roh, J.D.; Sawh-Martinez, R.; Brennan, M.P.; Jay, S.M.; Devine, L.; Rao, D.A.; Yi, T.; Mirensky, T.L.; Nalbandian, A.; Udelsman, B.; et al. Tissue-engineered vascular grafts transform into mature blood vessels via an inflammation-mediated process of vascular remodeling. Proc. Natl. Acad. Sci. USA 2010, 107, 4669-4674. [CrossRef] [PubMed]

12. Stowell, C.E.T.; Wang, Y. Quickening: Translational design of resorbable synthetic vascular grafts. Biomaterials 2018, 173, 71-86. [CrossRef] [PubMed]

13. Hibino, N.; McGillicuddy, E.; Matsumura, G.; Ichihara, Y.; Naito, Y.; Breuer, C.; Shinoka, T. Late-term results of tissue-engineered vascular grafts in humans. J. Thorac. Cardiovasc. Surg. 2010, 139, 431-436. [CrossRef] [PubMed] 
14. Williams, S.K.; Morris, M.E.; Kosnik, P.E.; Lye, K.D.; Gentzkow, G.D.; Ross, C.B.; Dwevidi, A.J.; Kleinert, L.B. Point-of-Care Adipose-Derived Stromal Vascular Fraction Cell Isolation and Expanded Polytetrafluoroethylene Graft Sodding. Tissue Eng. Part C Methods 2017, 23, 497-504. [CrossRef] [PubMed]

15. Sugiura, T.; Matsumura, G.; Miyamoto, S.; Miyachi, H.; Breuer, C.K.; Shinoka, T. Tissue-engineered Vascular Grafts in Children with Congenital Heart Disease: Intermediate Term Follow-up. Semin. Thorac. Cardiovasc. Surg. 2018, 30, 175-179. [CrossRef] [PubMed]

16. Lawson, J.H.; Glickman, M.H.; Ilzecki, M.; Jakimowicz, T.; Jaroszynski, A.; Peden, E.K.; Pilgrim, A.J.; Prichard, H.L.; Guziewicz, M.; Przywara, S.; et al. Bioengineered human acellular vessels for dialysis access in patients with end-stage renal disease: Two phase 2 single-arm trials. Lancet 2016, 387, 2026-2034. [CrossRef]

17. McAllister, T.N.; Maruszewski, M.; Garrido, S.A.; Wystrychowski, W.; Dusserre, N.; Marini, A.; Zagalski, K.; Fiorillo, A.; Avila, H.; Manglano, X.; et al. Effectiveness of haemodialysis access with an autologous tissue-engineered vascular graft: A multicentre cohort study. Lancet 2009, 373, 1440-1446. [CrossRef]

18. Shin'oka, T.; Matsumura, G.; Hibino, N.; Naito, Y.; Watanabe, M.; Konuma, T.; Sakamoto, T.; Nagatsu, M.; Kurosawa, H. Midterm clinical result of tissue-engineered vascular autografts seeded with autologous bone marrow cells. J. Thorac. Cardiovasc. Surg. 2005, 129, 1330-1338. [CrossRef]

19. Kačarević, Ž.P.; Rider, P.M.; Alkildani, S.; Retnasingh, S.; Smeets, R.; Jung, O.; Ivanišević, Z.; Barbeck, M. An Introduction to 3D Bioprinting: Possibilities, Challenges and Future Aspects. Materials 2018, 11, 2199. [CrossRef]

20. Shelmerdine, S.C.; Simcock, I.C.; Hutchinson, J.C.; Aughwane, R.; Melbourne, A.; Nikitichev, D.I.; Ong, J.-L.; Borghi, A.; Cole, G.; Kingham, E.; et al. 3D printing from microfocus computed tomography (micro-CT) in human specimens: Education and future implications. Br. J. Radiol. 2018, 91, 20180306. [CrossRef]

21. Sfondrini, M.F.; Gandini, P.; Malfatto, M.; Di Corato, F.; Trovati, F.; Scribante, A. Computerized Casts for Orthodontic Purpose Using Powder-Free Intraoral Scanners: Accuracy, Execution Time, and Patient Feedback. BioMed Res. Int. 2018, 2018, 1-8. [CrossRef] [PubMed]

22. Chia, H.N.; Wu, B.M. Recent advances in 3D printing of biomaterials. J. Biol. Eng. 2015, 9. [CrossRef] [PubMed]

23. Murphy, S.V.; Atala, A. 3D bioprinting of tissues and organs. Nat. Biotechnol. 2014, 32, 773-785. [CrossRef] [PubMed]

24. Borovjagin, A.V.; Ogle, B.M.; Berry, J.L.; Zhang, J. From Microscale Devices to 3D Printing: Advances in Fabrication of 3D Cardiovascular Tissues. Circ. Res. 2017, 120, 150-165. [CrossRef] [PubMed]

25. Mosadegh, B.; Xiong, G.; Dunham, S.; Min, J.K. Current progress in 3D printing for cardiovascular tissue engineering. Biomed. Mater. 2015, 10, 034002. [CrossRef] [PubMed]

26. Jia, W.; Gungor-Ozkerim, P.S.; Zhang, Y.S.; Yue, K.; Zhu, K.; Liu, W.; Pi, Q.; Byambaa, B.; Dokmeci, M.R.; Shin, S.R.; et al. Direct 3D bioprinting of perfusable vascular constructs using a blend bioink. Biomaterials 2016, 106, 58-68. [CrossRef] [PubMed]

27. Zhang, Y.; Yu, Y.; Akkouch, A.; Dababneh, A.; Dolati, F.; Ozbolat, I.T. In vitro study of directly bioprinted perfusable vasculature conduits. Biomater. Sci. 2015, 3, 134-143. [CrossRef] [PubMed]

28. Luo, Y.; Lode, A.; Gelinsky, M. Direct plotting of three-dimensional hollow fiber scaffolds based on concentrated alginate pastes for tissue engineering. Adv. Healthc. Mater. 2013, 2, 777-783. [CrossRef]

29. Liu, W.; Zhong, Z.; Hu, N.; Zhou, Y.; Maggio, L.; Miri, A.K.; Fragasso, A.; Jin, X.; Khademhosseini, A.; Zhang, Y.S. Coaxial extrusion bioprinting of 3D microfibrous constructs with cell-favorable gelatin methacryloyl microenvironments. Biofabrication 2018, 10, 024102. [CrossRef]

30. Mistry, P.; Aied, A.; Alexander, M.; Shakesheff, K.; Bennett, A.; Yang, J. Bioprinting Using Mechanically Robust Core-Shell Cell-Laden Hydrogel Strands. Macromol. Biosci. 2017, 17, 1600472. [CrossRef]

31. Hölzl, K.; Lin, S.; Tytgat, L.; Van Vlierberghe, S.; Gu, L.; Ovsianikov, A. Bioink properties before, during and after 3D bioprinting. Biofabrication 2016, 8, 032002. [CrossRef] [PubMed]

32. Gudapati, H.; Dey, M.; Ozbolat, I. A comprehensive review on droplet-based bioprinting: Past, present and future. Biomaterials 2016, 102, 20-42. [CrossRef] [PubMed]

33. $\mathrm{Xu}, \mathrm{T}$.; Jin, J.; Gregory, C.; Hickman, J.J.; Boland, T. Inkjet printing of viable mammalian cells. Biomaterials 2005, 26, 93-99. [CrossRef] [PubMed]

34. Ng, W.L.; Lee, J.M.; Yeong, W.Y.; Naing, M.W. Microvalve-based bioprinting_Process, bio-inks and applications. Biomater. Sci. 2017, 5, 632-647. [CrossRef] [PubMed] 
35. Saunders, R.E.; Gough, J.E.; Derby, B. Delivery of human fibroblast cells by piezoelectric drop-on-demand inkjet printing. Biomaterials 2008, 29, 193-203. [CrossRef] [PubMed]

36. Gittard, S.D.; Narayan, R.J. Laser direct writing of micro- and nano-scale medical devices. Expert Rev. Med. Devices 2010, 7, 343-356. [CrossRef]

37. Ligon, S.C.; Liska, R.; Stampfl, J.; Gurr, M.; Mülhaupt, R. Polymers for 3D Printing and Customized Additive Manufacturing. Chem. Rev. 2017, 117, 10212-10290. [CrossRef]

38. Schöneberg, J.; De Lorenzi, F.; Theek, B.; Blaeser, A.; Rommel, D.; Kuehne, A.J.C.; Kießling, F.; Fischer, H. Engineering biofunctional in vitro vessel models using a multilayer bioprinting technique. Sci. Rep. $2018,8$. [CrossRef]

39. Suri, S.; Han, L.-H.; Zhang, W.; Singh, A.; Chen, S.; Schmidt, C.E. Solid freeform fabrication of designer scaffolds of hyaluronic acid for nerve tissue engineering. Biomed. Microdevices 2011, 13, 983-993. [CrossRef]

40. Cui, H.; Nowicki, M.; Fisher, J.P.; Zhang, L.G. 3D Bioprinting for Organ Regeneration. Adv. Healthc. Mater. 2017, 6, 1601118. [CrossRef]

41. Park, J.Y.; Shim, J.-H.; Choi, S.-A.; Jang, J.; Kim, M.; Lee, S.H.; Cho, D.-W. 3D printing technology to control BMP-2 and VEGF delivery spatially and temporally to promote large-volume bone regeneration. J. Mater. Chem. B 2015, 3, 5415-5425. [CrossRef]

42. Mota, C.; Puppi, D.; Chiellini, F.; Chiellini, E. Additive manufacturing techniques for the production of tissue engineering constructs: Additive manufacturing techniques for the production of tissue engineering constructs. J. Tissue Eng. Regen. Med. 2015, 9, 174-190. [CrossRef] [PubMed]

43. Gopinathan, J.; Noh, I. Recent trends in bioinks for 3D printing. Biomater. Res. 2018, 22, 11. [CrossRef] [PubMed]

44. Ouyang, L.; Yao, R.; Zhao, Y.; Sun, W. Effect of bioink properties on printability and cell viability for 3D bioplotting of embryonic stem cells. Biofabrication 2016, 8, 035020. [CrossRef] [PubMed]

45. Chung, J.H.Y.; Naficy, S.; Yue, Z.; Kapsa, R.; Quigley, A.; Moulton, S.E.; Wallace, G.G. Bio-ink properties and printability for extrusion printing living cells. Biomater. Sci. 2013, 1, 763-773. [CrossRef]

46. Tabriz, A.G.; Hermida, M.A.; Leslie, N.R.; Shu, W. Three-dimensional bioprinting of complex cell laden alginate hydrogel structures. Biofabrication 2015, 7, 045012. [CrossRef]

47. Visser, J.; Peters, B.; Burger, T.J.; Boomstra, J.; Dhert, W.J.A.; Melchels, F.P.W.; Malda, J. Biofabrication of multi-material anatomically shaped tissue constructs. Biofabrication 2013, 5, 035007. [CrossRef]

48. Pinnock, C.B.; Meier, E.M.; Joshi, N.N.; Wu, B.; Lam, M.T. Customizable engineered blood vessels using 3D printed inserts. Methods 2016, 99, 20-27. [CrossRef]

49. Hinton, T.J.; Jallerat, Q.; Palchesko, R.N.; Park, J.H.; Grodzicki, M.S.; Shue, H.-J.; Ramadan, M.H.; Hudson, A.R.; Feinberg, A.W. Three-dimensional printing of complex biological structures by freeform reversible embedding of suspended hydrogels. Sci. Adv. 2015, 1, e1500758. [CrossRef]

50. Xu, Y.; Hu, Y.; Liu, C.; Yao, H.; Liu, B.; Mi, S. A Novel Strategy for Creating Tissue-Engineered Biomimetic Blood Vessels Using 3D Bioprinting Technology. Materials 2018, 11, 1581. [CrossRef]

51. Baudis, S.; Nehl, F.; Ligon, S.C.; Nigisch, A.; Bergmeister, H.; Bernhard, D.; Stampfl, J.; Liska, R. Elastomeric degradable biomaterials by photopolymerization-based CAD-CAM for vascular tissue engineering. Biomed. Mater. 2011, 6, 055003. [CrossRef] [PubMed]

52. Mishra, R.; Roux, B.M.; Posukonis, M.; Bodamer, E.; Brey, E.M.; Fisher, J.P.; Dean, D. Effect of prevascularization on in vivo vascularization of poly(propylene fumarate)/ fibrin scaffolds. Biomaterials 2016, 77, 255-266. [CrossRef] [PubMed]

53. Melchiorri, A.J.; Hibino, N.; Best, C.A.; Yi, T.; Lee, Y.U.; Kraynak, C.A.; Kimerer, L.K.; Krieger, A.; Kim, P.; Breuer, C.K.; et al. 3D-Printed Biodegradable Polymeric Vascular Grafts. Adv. Healthc. Mater. 2016, 5, 319-325. [CrossRef] [PubMed]

54. Meyer, W.; Engelhardt, S.; Novosel, E.; Elling, B.; Wegener, M.; Krüger, H. Soft Polymers for Building up Small and Smallest Blood Supplying Systems by Stereolithography. J. Funct. Biomater. 2012, 3, 257-268. [CrossRef] [PubMed]

55. Kesari, P.; Xu, T.; Boland, T. Layer-by-layer printing of cells and its application to tissue engineering. MRS Proceed. 2004, 845. [CrossRef]

56. Lee, S.J.; Heo, D.N.; Park, J.S.; Kwon, S.K.; Lee, J.H.; Lee, J.H.; Kim, W.D.; Kwon, I.K.; Park, S.A. Characterization and preparation of bio-tubular scaffolds for fabricating artificial vascular grafts by 
combining electrospinning and a 3D printing system. Phys. Chem. Chem. Phys. 2015, 17, 2996-2999. [CrossRef]

57. Centola, M.; Rainer, A.; Spadaccio, C.; De Porcellinis, S.; Genovese, J.A.; Trombetta, M. Combining electrospinning and fused deposition modeling for the fabrication of a hybrid vascular graft. Biofabrication 2010, 2, 014102. [CrossRef]

58. Spadaccio, C.; Nappi, F.; De Marco, F.; Sedati, P.; Sutherland, F.W.H.; Chello, M.; Trombetta, M.; Rainer, A. Preliminary in Vivo Evaluation of a Hybrid Armored Vascular Graft Combining Electrospinning and Additive Manufacturing Techniques: Supplementary Issue: Current Developments in Drug Eluting Devices. Drug Target Insights 2016, 10, DTI-S35202. [CrossRef]

59. Alemán, J.V.; Chadwick, A.V.; He, J.; Hess, M.; Horie, K.; Jones, R.G.; Kratochvíl, P.; Meisel, I.; Mita, I.; Moad, G.; et al. Definitions of terms relating to the structure and processing of sols, gels, networks, and inorganic-organic hybrid materials (IUPAC Recommendations 2007). Pure Appl. Chem. 2007, 79, 1801-1829. [CrossRef]

60. Hoffman, A.S. Hydrogels for biomedical applications. Adv. Drug Deliv. Rev. 2012, 64, 18-23. [CrossRef]

61. Guvendiren, M.; Molde, J.; Soares, R.M.D.; Kohn, J. Designing Biomaterials for 3D Printing. ACS Biomater. Sci. Eng. 2016, 2, 1679-1693. [CrossRef] [PubMed]

62. Tsai, Y.-C.; Li, S.; Hu, S.-G.; Chang, W.-C.; Jeng, U.-S.; Hsu, S. Synthesis of Thermoresponsive Amphiphilic Polyurethane Gel as a New Cell Printing Material near Body Temperature. ACS Appl. Mater. Interfaces 2015, 7, 27613-27623. [CrossRef] [PubMed]

63. Hsieh, F.-Y.; Lin, H.-H.; Hsu, S. 3D bioprinting of neural stem cell-laden thermoresponsive biodegradable polyurethane hydrogel and potential in central nervous system repair. Biomaterials 2015, 71, 48-57. [CrossRef] [PubMed]

64. Engelhardt, S.; Hoch, E.; Borchers, K.; Meyer, W.; Krüger, H.; Tovar, G.E.M.; Gillner, A. Fabrication of 2D protein microstructures and 3D polymer-protein hybrid microstructures by two-photon polymerization. Biofabrication 2011, 3, 025003. [CrossRef] [PubMed]

65. Lee, K.Y.; Mooney, D.J. Alginate: Properties and biomedical applications. Prog. Polym. Sci. 2012, 37, $106-126$. [CrossRef] [PubMed]

66. Woodruff, M.A.; Hutmacher, D.W. The return of a forgotten polymer-Polycaprolactone in the 21st century. Prog. Polym. Sci. 2010, 35, 1217-1256. [CrossRef]

67. Boland, E.D.; Pawlowski, K.J.; Barnes, C.P.; Simpson, D.G.; Wnek, G.E.; Bowlin, G.L. Electrospinning of Bioresorbable Polymers for Tissue Engineering Scaffolds. In Polymeric Nanofibers; Reneker, D.H., Fong, H., Eds.; American Chemical Society: Washington, DC, USA, 2006; Volume 918, pp. 188-204. ISBN 978-0-8412-3919-7.

68. Jiang, T.; Carbone, E.J.; Lo, K.W.-H.; Laurencin, C.T. Electrospinning of polymer nanofibers for tissue regeneration. Prog. Polym. Sci. 2015, 46, 1-24. [CrossRef]

69. Mauck, R.L.; Baker, B.M.; Nerurkar, N.L.; Burdick, J.A.; Li, W.-J.; Tuan, R.S.; Elliott, D.M. Engineering on the Straight and Narrow: The Mechanics of Nanofibrous Assemblies for Fiber-Reinforced Tissue Regeneration. Tissue Eng. Part B Rev. 2009, 15, 171-193. [CrossRef] [PubMed]

70. Vijayavenkataraman, S.; Yan, W.-C.; Lu, W.F.; Wang, C.-H.; Fuh, J.Y.H. 3D bioprinting of tissues and organs for regenerative medicine. Adv. Drug Deliv. Rev. 2018. [CrossRef]

71. Mironov, V.; Visconti, R.P.; Kasyanov, V.; Forgacs, G.; Drake, C.J.; Markwald, R.R. Organ printing: Tissue spheroids as building blocks. Biomaterials 2009, 30, 2164-2174. [CrossRef] [PubMed]

72. Norotte, C.; Marga, F.S.; Niklason, L.E.; Forgacs, G. Scaffold-free vascular tissue engineering using bioprinting. Biomaterials 2009, 30, 5910-5917. [CrossRef] [PubMed]

73. Kucukgul, C.; Ozler, S.B.; Inci, I.; Karakas, E.; Irmak, S.; Gozuacik, D.; Taralp, A.; Koc, B. 3D bioprinting of biomimetic aortic vascular constructs with self-supporting cells: 3D Bioprinting of Biomimetic Aortic Vascular Constructs. Biotechnol. Bioeng. 2015, 112, 811-821. [CrossRef] [PubMed]

74. Elomaa, L.; Pan, C.-C.; Shanjani, Y.; Malkovskiy, A.; Seppälä, J.V.; Yang, Y. Three-dimensional fabrication of cell-laden biodegradable poly(ethylene glycol-co-depsipeptide) hydrogels by visible light stereolithography. J. Mater. Chem. B 2015, 3, 8348-8358. [CrossRef] [PubMed]

75. Shanjani, Y.; Pan, C.C.; Elomaa, L.; Yang, Y. A novel bioprinting method and system for forming hybrid tissue engineering constructs. Biofabrication 2015, 7, 045008. [CrossRef] [PubMed] 
76. Itoh, M.; Nakayama, K.; Noguchi, R.; Kamohara, K.; Furukawa, K.; Uchihashi, K.; Toda, S.; Oyama, J.; Node, K.; Morita, S. Scaffold-Free Tubular Tissues Created by a Bio-3D Printer Undergo Remodeling and Endothelialization when Implanted in Rat Aortae. PLoS ONE 2015, 10, e0136681. [CrossRef]

77. Christensen, K.; Xu, C.; Chai, W.; Zhang, Z.; Fu, J.; Huang, Y. Freeform inkjet printing of cellular structures with bifurcations: Approach Freeform Fabrication of Bifurcated Cellular Structures by Using a Liquid Support-Based Inkjet Printing Approach. Biotechnol. Bioeng. 2015, 112, 1047-1055. [CrossRef] [PubMed]

78. Ji, S.; Guvendiren, M. Recent Advances in Bioink Design for 3D Bioprinting of Tissues and Organs. Front. Bioeng. Biotechnol. 2017, 5, 23. [CrossRef] [PubMed]

79. Gelinsky, M. 6-Biopolymer hydrogel bioinks. In 3D Bioprinting for Reconstructive Surgery; Thomas, D.J., Jessop, Z.M., Whitaker, I.S., Eds.; Elsevier Science \& Technology: Cambridge, UK, 2018; pp. 125-136. ISBN 978-0-08-101103-4.

80. Chua, C.K.; Yeong, W.Y. Bioprinting; World Scientific Series in 3D Printing; World Scientific: Singapore, 2014; Volume 1, ISBN 978-981-4612-10-4.

81. Ulrich, T.A.; Jain, A.; Tanner, K.; MacKay, J.L.; Kumar, S. Probing cellular mechanobiology in three-dimensional culture with collagen-agarose matrices. Biomaterials 2010, 31, 1875-1884. [CrossRef]

82. Tarassoli, S.P.; Jessop, Z.M.; Kyle, S.; Whitaker, I.S. Candidate bioinks for 3D bioprinting soft tissue. In 3D Bioprinting for Reconstructive Surgery; Elsevier Science \& Technology: Cambridge, UK, 2018; pp. 145-172. ISBN 978-0-08-101103-4.

83. Janmey, P.A.; Winer, J.P.; Weisel, J.W. Fibrin gels and their clinical and bioengineering applications. J. R. Soc. Interface 2009, 6, 1-10. [CrossRef]

84. Antoine, E.E.; Vlachos, P.P.; Rylander, M.N. Review of Collagen I Hydrogels for Bioengineered Tissue Microenvironments: Characterization of Mechanics, Structure, and Transport. Tissue Eng. Part B Rev. 2014, 20, 683-696. [CrossRef]

85. Yue, K.; Trujillo-de Santiago, G.; Alvarez, M.M.; Tamayol, A.; Annabi, N.; Khademhosseini, A. Synthesis, properties, and biomedical applications of gelatin methacryloyl (GelMA) hydrogels. Biomaterials 2015, 73, 254-271. [CrossRef] [PubMed]

86. Alexander, A.; Khan, J.; Saraf, S.; Saraf, S. Poly(ethylene glycol)-poly(lactic-co-glycolic acid) based thermosensitive injectable hydrogels for biomedical applications. J. Control. Release 2013, 172, 715-729. [CrossRef] [PubMed]

87. Pereira, R.F.; Bártolo, P.J. 3D bioprinting of photocrosslinkable hydrogel constructs. J. Appl. Polym. Sci. 2015, 132. [CrossRef]

88. Guvendiren, M.; Burdick, J.A. Engineering synthetic hydrogel microenvironments to instruct stem cells. Curr. Opin. Biotechnol. 2013, 24, 841-846. [CrossRef] [PubMed]

89. Zhang, M.; Desai, T.; Ferrari, M. Proteins and cells on PEG immobilized silicon surfaces. Biomaterials 1998, 19, 953-960. [CrossRef]

90. Deshmukh, M.; Singh, Y.; Gunaseelan, S.; Gao, D.; Stein, S.; Sinko, P.J. Biodegradable poly(ethylene glycol) hydrogels based on a self-elimination degradation mechanism. Biomaterials 2010, 31, 6675-6684. [CrossRef] [PubMed]

(C) 2018 by the authors. Licensee MDPI, Basel, Switzerland. This article is an open access article distributed under the terms and conditions of the Creative Commons Attribution (CC BY) license (http://creativecommons.org/licenses/by/4.0/). 